\title{
Hubungan Keteraturan Antenalcare Dengan Persalinan Tenaga Kesehatan Di Puskesmas Mangkung Kabupaten Lombok Tengah Tahun 2018
}

\author{
Baiq. Lina Ermawati'), Dita Retno Pratiwi' ${ }^{2)}$, Siti Maryam²) \\ Email: linaermawati@hotmail.com \\ ${ }^{1}$ Mahasiswa DIII Prodi Kebidanan UNIQHBA \\ ${ }^{2}$ Prodi Kebidanan UNIQHBA
}

\begin{abstract}
ABSTRAK
Antenatal Care (ANC) sebagai salah satu upaya pencegahan awal dari faktor resiko kehamilan. Menurut Organisasi Kesehatan Dunia (WHO) Antenatal care untuk mendeteksi dini terjadinya resiko tinggi terhadap kehamilan dan persalinan juga dapat menurunkan angka kematian ibu dan memantau keadaan janin. Beberapa faktor yang berpengaruh terhadap tingginya angka kamatian ibu adalah sikap dan perilaku ibu itu sendiri selama hamil dan didukung oleh pengetahuan ibu terhadap kehamilannya. Tujuan penelitian ini adalah untuk mengetahui hubungan keteraturan ANC dengan persalinan oleh tenaga kesehatan di Puskesmas Mangkung Kecamatan Praya Barat Kabupaten Lombok Tengah tahun 2018. Desain penelitian ini menggunakan observasional analitik, dan dari segi waktu desain penelitian ini adalah retrosfektif. Populasinya adalah seluruh ibu yang pernah melahirkan yang berada di Pukesmas Mangkung Kabupaten Lombok Tengah pada Bulan Juli - Desember tahun 2017 sebanyak 60 ibu. Berdasarkan hasil penelitian didapatkan paling banyak Ibu yang bersalin di Non Nakes yaitu sebanyak 45 responden $(75,0 \%)$. Berdasarkan hasil uji statistik Chi Square pada tingkat kesalahan 5\% $(\alpha=0,05)$ didapatkan nilai signifikan (p) yaitu 0,009. Dapat ditarik kesimpulan bahwa $\mathrm{p}<\alpha$, sehingga $\mathrm{H} 0$ ditolak dan Ha diterima, artinya ada hubungan yang antara keteraturan kunjungan ANC dengan persalinan tenaga kesehatan.
\end{abstract}

Kata Kunci: ANC, Persalinan, Tenaga Kesehatan

\begin{abstract}
Antenatal Care (ANC) as one of the early prevention efforts of pregnancy risk factors. According to the World Health Organization (WHO) Antenatal care to detect early occurrence of high risk of pregnancy and childbirth can also reduce maternal mortality and monitor the state of the fetus. Some factors that affect the high rate of maternal death is the attitude and behavior of the mother herself during pregnancy and supported by mother's knowledge of her pregnancy. The purpose of this study was to determine the relationship of regularity of ANC with delivery by health personel at Mangkung Primary health center, West Praya Sub-district, Central Lombok District, 2018. The design of this study used observational analytic, and in terms of time this research design is retrospectively. The population is all mothers who have given birth in Mangkung Primary health center, Central Lombok Regency in July - December of 2017 as many as 60 mothers. Based on the results of the research, most of the mothers who were born in non health provider were 45 respondents $(75 \%)$. Based on Chi Square statistical test at $5 \%$ error rate $(\alpha=0,05)$ got significant whose $p$ value that is 0,009 . It can be deduced that $\mathrm{p}<\alpha$, so $\mathrm{H} 0$ is rejected and Ha accepted, meaning there is a significant relationship between antenatal care visit arrangement with health provider.
\end{abstract}

Keywords: Antenatal Care, labor, health provider 


\section{A. LATAR BELAKANG}

Program pembangunan kesehatan yang telah di laksanakan selama ini telah berhasil meningkatkan derajat kesehatan masyarakat secara cukup bermakna, walaupun masih di jumpai berbagai masalah dan hambatan yang akan mempengaruhi pelaksanaan pembangunan kesehatan. Salah satu indikator untuk mengukur derajat kesehatan antara lain adalah Angka Kematian Ibu (AKI). Berdasarkan data Survei Demografi dan Kesehatan Indonesia (SDKI) 2007 AKI Indonesia sebesar 228 per 100.000 kelahiran hidup, meskipun demikian angka tersebut masih tertinggi di Asia. Angkaangka tersebut sekitar 3-6 kali dari AKI negara-negara Association of Southeast Asian Nation (ASEAN) dan lebih dari 50 kali AKI negara maju. Sementara target Rencana Pembangunan Jangka Menengah Nasional (RPJMN) adalah sebesar 226 per 100.000 kelahiran hidup (SDKI, 2007).

Angka kematian ibu dan bayi merupakan tolak ukur dalam menilai derajat kesehatan bangsa, oleh karena itu, pemerintah sangat menekankan untuk menurunkan angka kematian ibu dan bayi melalui program-program kesehatan. Dalam pelaksanaan program kesehatan sangat dibutuhkan sumber daya manusia yang kompeten, sehingga apa yang menjadi tujuan bisa tercapai. Sebagai salah satu sumber daya manusia bidan kesehatan merupakan ujung tombak atau orang yang berada di garis terdepan yang berhubungan langsung dengan perempuan sebagai sasaran program. Dengan peranan yang cukup besar ini, sangat penting kiranya bagi bidan untuk senantiasa meningkatkan kompetensinya melalui pemahaman mengenai asuhan kebidanan, mulai dari perempuan hamil sampai nifas serta kesehatan bayi. (Hennderson, 2006)

Salah satu faktor yang berpengaruh terhadap tingginya angka kamatian ibu adalah sikap dan perilaku ibu itu sendiri selama hamil dan didukung oleh pengetahuan ibu terhadap kehamilannya. Beberapa faktor yang melatar belakangi resiko kematian ibu tersebut adalah kurangnya partisipasi masyarakat yang disebabkan tingkat pendidikan ibu rendah, kemampuan ekonomi keluarga rendah, kedudukan sosial budaya yang tidak mendukung. Jika ditarik lebih jauh beberapa perilaku tidak mendukung tersebut juga bisa membawa resiko (Wahyuni, 2012). Selain faktor faktor diatas letak georafis sangat menentukan terhadap pelayanan kesehatan, ditempat yang terpencil ibu hamil sulit memeriksakan kehamilannya, hal ini karena transpontasi yang sulit menjangkau sampai tempat terpencil (Depkes RI, 2009). Faktor jarak yang jauh kadang menimbulkan keengganan seseorang untuk hadir atau datang ketempat yang dirasakan jauh dari tempat tinggal. (Depkes RI, 2006).

Kunjungan antenatal yang dilakukan setelah kunjungan antenatal pertama, Perempuan hamil seharusnya melakukan minimal 4 kali kunjungan antenatal selama kehamilan. Karena bayak dari riwayat ibu dan pemeriksaan fisik telah lengkap selama kunjungan antenatal pertama, kunjungan ulang difokuskan pada pendeteksian komplikasi-komplikasi, kegawatdaruratan, atau tanda bahaya melalui pemeriksaan fisik atau laboratorium, persiapan kelahiran dan pemberian pendidikan kesehatan dan informasi yang diperoleh dari pemeriksaan antenatal akan memungkinkan bidan dan ibu hamil menetapkan pola asuhan antenatal yang tepat (Salman, dkk. 2006).

Data yang di dapat dari BKKBN di Indonesia tahun 2013 di dapatkan cakupan antenatal K4 sebesar 87,37\% ibu hamil dengan target $95 \%$, di Provensi Nusa Tenggara Barat di dapatkan cakupan antental K4 tahun 2012 sebesar 91,40\% dari target 95\% dan pada tahun 2013 di dapatkan sebesar $91,60 \%$ dari target $95 \%$, (Dikes, 2012) sedangkan di kabupaten Lombok Tengah di dapatkan angka cakupan antenatal K4 tahun 2012 sebesar 93,49\% dan pada tahun $2013 \mathrm{~K} 1$ sebesar $21.875(93,71 \%)$ dari target $95,00 \%$, cakupan k4 sebesar $20.030(91,30 \%)$ dari target 95,00\% (Dinkes NTB, 2013).

Berdasarkan hasil studi pendahuluan dan pengambilan yang dilakukan di Puskesmas Mangkung pada bulan Maret 
tahun 2014 di dapatkan cakupan antental care, yaitu sebagai berikut: pada tahun 2012 jumlah ibu hamil di puskesmas mangkung yaitu 821 orang, yang memilih bersalin di Linakes sebanyak 720 orang $(60,2 \%)$ dan non nakes sebanyak 2 orang (1.02\%). Pada tahun 2013 tercatat sebanyak 811 ibu hamil, 599 diantaranya memilih bersalin di Linakes dan 13 orang $(0,13)$ memilih bersalin di non nakes.

Tujuan dari penelitian in adalah untuk mengetahui hubungan keteraturan ANC dengan persalinan oleh tenaga kesehatan di Puskesmas Mangkung Kecamatan Praya Barat Kabupaten Lombok Tengah tahun 2018 .

\section{B. METODE PENELITIAN}

Jenis penelitian ini menggunakan metode penelitian deskriftif korelasi yaitu penelitian yang digunakan untuk melihat hubungan antara variabel independen (keteraturan ANC) dengan variabel dependen (pemilihan penolong persalinan). Data yang dikumpulkan dalam penelitian ini adalah data sekunder yang diambil dari catatan kohort ibu di puskesmas mangkung.

Populasi dalam penelitian ini adalah seluruh ibu melahirkan yang tercatat di Kohort Ibu Puskesmas Mangkung Kabupaten Lombok Tengah pada Bulan Juli - Desember Tahun 2017 sebanyak 60 ibu. Sampel dalam penelitian ini adalah ibu melahirkan yang tercatat di Kohort Ibu Puskesmas Mangkung Kabupaten Lombok Tengah pada Bulan Juli - Desember Tahun 2017 sebanyak $60 \mathrm{ibu}$. Teknik pengambilan sampel dalam penelitian ini adalah total sampling, dimana mengambil seluruh populasi yang ada sebagai sampel penelitian.

\section{HASIL DAN PEMBAHASAN}

Berdasarkan hasil penelitian mengenai hubungan keteraturan ANC dengan penolong persalinan di di Puskesmas Mangkung Kabupaten Lombok Tengah, didapatkan hasil sebagai berikut:

Dari hasil pengolahan data didapatkan hasil sebagai berikut:
1. Analisis Univariat

a. Keteraturan ANC

Tabel 1 Distribusi Frekuensi Responden Berdasarkan Keteraturan ANC di Puskesmas Mangkung

\begin{tabular}{|l|l|l|}
\hline $\begin{array}{c}\text { Keteraturan } \\
\text { ANC }\end{array}$ & Jumlah & $\begin{array}{l}\text { Persentase } \\
(\%)\end{array}$ \\
\hline Teratur & 8 & 13,3 \\
Tidak Teratur & 52 & 86,7 \\
\hline Jumlah & 60 & 100 \\
\hline
\end{tabular}

Berdasarkan tabel di atas dapat diketahui bahwa dari 60 responden yang paling banyak yaitu kunjungan ANC tidak teratur sebanyak 52 responden $(86,7 \%)$, dan yang paling sedikit yang melakukan kunjungan ANC secara teratur yaitu 8 responden $(13,3 \%)$.

Hasil penelitian menunjukkan sebagian besar responden dengan kunjungan ANC tidak teratur, hal ini dikarenakan akses menuju tenaga kesehatan dari desa yang masih belum memadai dan jarak antara desa dengan tenaga kesehatan yang cukup jauh sehingga responden lebih banyak yang memilih untuk tidak memeriksakan kehamilannya secara lengkap dan teratur ke tenaga kesehatan (Syafrudin, 2009).

Penelitian ini sejalan dengan penelitian yang dilakukan oleh Rahma, 2007 dengan judul Hubungan antara kepatuhan ANC dengan pemilihan penolong persalinan, Hasilnya lebih banyak ibu dengan kunjungan ANC yang tidak teratur yaitu sebanyak 46 orang dari 77 responden $(59,7 \%)$.

Setiap kehamilan dapat berkembang menjadi masalah atau komplikasi setiap saat.Itu sebabnya ibu hamil memerlukan pemantauan atau monitoring salah satunya yaitu pemeriksaan kehamilan. Bagi ibu hamil dan atau keluarga dapat mengubah pola berpikir yang hanya datang kedokter jika ada permasalahan dengan kehamilannya. Karena dengan pemeriksaan kehamilan yang teratur, diharapkan proses persalinan dapat berjalan dengan lancer dan selamat. Dan yang tak kalah penting adalah kondisi bayi yang dilahirkan juga sehat, begitu pula dengan ibunya (salman,dkk. 2006). 
b. Penolong Persalinan

Tabel 2 Distribusi Frekuensi Responden Berdasarkan Penolong Persalinan di Puskesmas Mangkung

\begin{tabular}{|l|l|l|}
\hline $\begin{array}{c}\text { Penolong } \\
\text { persalinan }\end{array}$ & Jumlah & \multicolumn{1}{|c|}{$\begin{array}{c}\text { Persentase } \\
(\%)\end{array}$} \\
\hline Nakes & 15 & 75 \\
Non Nakes & 45 & 25 \\
\hline Jumlah & 60 & 100 \\
\hline
\end{tabular}

Berdasarkan tabel di atas dapat diketahui bahwa dari 60 responden yang paling banyak yaitu yang bersalin di Non Nakes sebanyak 45 responden (75\%), dan yang paling sedikit yang bersalin di Nakes yaitu sebanyak 15 responden (25\%).

Pertolongan persalinan adalah suatu bentuk pelayanan terhadap ibu melahirkan yang dilakukan oleh penolong persalinan baik oleh tenaga kesehatan seperti dokter dan bidan atau non tenaga kesehatan seperti dukun (Syafrudin, 2009).

Tenaga yang dapat memberikan pertolongan selama persalinan dapat dibedakan menjadi dua yaitu tenaga kesehatan dan bukan tenaga kesehatan, yaitu dukun bayi yang terlatih dan tidak terlatih (Prawirohardjo, 2007).

Hasil penelitian menunjukkan sebagian besar responden bersalin di non tenaga kesehatan, hal ini dikarenakan jarak tenaga kesehatan yang jauh serta jalan raya menuju tenaga kesehatan yang jelek dan faktor kurangnya pengetahuan dan sikap tentang hal yang bekaitan dengan persalinan.

Penelitian ini sejalan dengan penelitian yang dilakukan oleh Wahyu Utami, 2006, dengan judul Hubungan Frekuensi Kunjungan ANC dengan Pemanfaatan Pelayanan Kesehatan sebagai Penolong Persalinan menyebutkan bahwa responden yang bersalin di tenaga Non Nakes lebih banyak yaitu sebanyak 56\%.

\section{Analisis Bivariat}

Analisis bivariat ini digunakan untuk mengetahui hubungan keteraturan ANC dengan penolong persalinan di Puskesmas Mangkung. Untuk mengetahui hubungan tersebut dilakukan uji chi square sehingga didapatkan hasil sebagai berikut:
Tabel 3 Hubungan status pekerjaan ibu hamil dengan partisipasi mengikuti kelas ibu di Puskesmas Mangkung

\begin{tabular}{|l|c|c|c|c|c|c|c|}
\hline \multirow{3}{*}{$\begin{array}{c}\text { Keteraturan } \\
\text { ANC }\end{array}$} & \multicolumn{2}{|c|}{ Nakes } & \multicolumn{2}{|l|}{$\begin{array}{l}\text { Non } \\
\text { Nakes }\end{array}$} & \multicolumn{2}{|c|}{ Total } & \multirow{2}{*}{$\begin{array}{c}p \\
\text { val } \\
\text { ue }\end{array}$} \\
\cline { 2 - 7 } & $\mathrm{f}$ & $\%$ & $\mathrm{f}$ & $\%$ & $\mathrm{f}$ & $\%$ & \\
\hline Teratur & 5 & 8,3 & 3 & 5 & 8 & 13 '3 & $\begin{array}{c}0,0 \\
09\end{array}$ \\
\hline Tidak teratur & 10 & 16,7 & 42 & 70 & 52 & 86,7 & \\
\hline Jumlah & 15 & 25 & 45 & 75 & 60 & 100 & \\
\hline
\end{tabular}

Berdasarkan tabel diatas, diperoleh hasil bahwa persentasi persalinan oleh tenaga kesehatan pada ibu dengan kunjungan ANC tidak teratur yang bersalin di Nakes yaitu sebesar 16,7\%, dan Non Nakes sebesar 70,0\% sehingga dari pemeriksaan ANC tidak teratur berjumlah sebesar $86,7 \%$, lebih besar dari persalinan oleh tenaga kesehatan dengan kunjungan ANC teratur yang bersalin di Nakes sebesar 8,3\%, dan Non Nakes sebesar 5,0\% sehingga dari pemeriksaan ANC teratur berjumlah sebesar 13,3\% .

Ibu dengan kunjungan ANC teratur lebih banyak yang bersalin ke tenaga kesehatan dibandingkan ibu dengan kunjungan ANC tidak teratur. Berdasarkan hasil uji statistik Chi Square pada tingkat kesalahan 5\% $(\alpha=0,05)$ didapatkan nilai signifikan (p) yaitu 0,009. Dapat ditarik kesimpulan bahwa $\mathrm{p}<\alpha$, sehingga $\mathrm{H} 0$ ditolak dan $\mathrm{Ha}$ diterima, artinya ada hubungan yang signifikan antara Keteraturan Kunjungan ANC dengan Persalinan Tenaga Kesehatan

Pemeriksaan antenatal yang teratur, minimal 4 kali selama kehamilan kepada petugas kesehatan, maka kemungkinan komplikasi yang akan timbul dapat di prediksi sejak awal sehingga persalinan dapat direncanakan lebih optimal. Frekuensi ANC yang tidak sesuai dengan standar minimal yang diharapkan berimplikasi terhadap rendahnya kualitas pelayanan yang diterima sehingga kemungkinan risiko maupun komplikasi yang terjadi pada saat kehamilan maupun persalinan tidak dapat di perkirakan. Dengan sendirinya perencanaan persiapan persalinan tidak dapat di lakukan dengan maksimal, sehingga ibu-ibu cenderung 
melahirkan di tenaga non kesehatan atau dukun (Manuaba, 2010).

Pengetahuan dan sikap tentang hal yang bekaitan dengan persalinan merupakan salah satu faktor yang mempengaruhi seseorang untuk memanfaatkan pelayanan kesehatan dalam menolong persalinannya baik oleh tenaga kesehatan maupun non kesehatan, semua hal yang berkaitan dengan pengetahuan masalah kehamilan dan melahirkan tersebut akan diperoleh apa bila ibu hamil melakukan ANC secara teratur (Depkes RI, 2007).

\section{KESIMPULAN}

Berdasarkan penelitian yang telah dilakukan dan pembahasan pada bab sebelumnya serta merujuk pada tujuan khusus penelitian ini, maka peneliti dapat menarik kesimpulan antara lain:

Tingkat keteraturan ANC di Puskesmas Mangkung sebagian besar tidak teratur sebayak 52 responden (86,7\%). Jumlah persalinan di Puskesmas Mangkung sebagian besar di Non Nakes sebayak 45 responden $(75,0 \%)$. Ada hubungan antara keteraturan kunjungan ANC dengan Persalinan Tenaga Kesehatan ( $\mathrm{p}$ value $=0,009)$.

\section{DAFTAR PUSTAKA}

[1] Depertemen Kesehatan RI. 2007. Profil Kesehatan Indonesia. Jakarta: Departemen Kesehatan RI.

[2] Dinas Kesehatan Lombok Tengah. 2016. Profil Kesehatan Kabupaten Lombok Barat

[3] Dinas Kesehatan Provinsi NTB. 2015. Profil Kesehatan NTB

[4] Henderson, C. (2006). Buku Ajar kebidanan. Jakarta. EGC

[5] Hidayat A.A. (2010). Metode Penelitian dan Teknik Analisis Data. Jakarta: Salemba Medika.

[6] Kemenkes RI. (2014). Info Datin Ibu: Situasi Kesehatan Ibu. Jakarta: Kementerian Kesehatan Republik Indonesia

[7] Manuaba. (2010). Ilmu Kebidanan Penyakit Kandungan Dan Keluarga Berencana. Jakarta:EGC
[8] Prawirohardjo, S. (2008). Ilmu Kandungan. Jakarta:Yayasan Bina Pustaka

[9] Saifuddin, A.B., 2002. Buku Panduan Praktis Pelayanan Kesehatan Maternal dan Neonatal. Jakarta: Yayasan Bina Pustaka

[10] Saifuddin, ddk. 2004. Pelayanan Kesehatan Maternal Neonatal. Jakarta: PT Binapustaka Sarwono prawirohardjo.

[11] Sarwono. P. 2008. Ilmu Kebidanan. Jakarta: PT Bina Pustaka Sarwono Prawirohardjo.

[12] Sulistyawati, A. 2013. Asuhan Kebidanan Pada Masa Kehamilan. Jakarta:Salemba Medika.

[13] Wahyuni, A. 2013. Hubungan Pengetahuan Dan Sikap Ibu Dengan Persalinan Preterm Di Ruang Bersalin Rumah Sakit Umum Meuraxa Kota Banda Aceh Tahun 2012. Jurnal Ilmiah STIKes U'Budiyah. Vol.2, No.1, Maret 2013 